
\title{
28 Research Suare \\ Detection of Escherichia albertii in urinary and gastrointestinal infections in Kermanshah, Iran
}

\author{
Afshin Namdari \\ Islamic azad university \\ Bahareh Rahimian-zarif \\ Department of Biology, Azad Islamic University, Sanandaj baranch \\ Azadeh Foroughi ( $\square$ a.foroughi@razi.ac.ir) \\ Razi University https://orcid.org/0000-0002-5917-1985
}

\section{Research article}

Keywords: Escherichia albertii, Escherichia coli, PCR, urinary tract infection, gastrointestinal infection

Posted Date: June 18th, 2020

DOI: https://doi.org/10.21203/rs.3.rs-32416/v1

License: (1) This work is licensed under a Creative Commons Attribution 4.0 International License. Read Full License 


\section{Abstract \\ Background}

Escherichia albertii (E. albertii) is a Gram-negative and facultative anaerobe bacterium. In recent years, the bacterium has been isolated from the feces of people with gastroenteritis as a pathogen that causes diarrhea. Due to insufficient information on the phenotypic and biochemical characteristics of $E$. albertii, it is difficult to distinguish it from other species of the Enterobacteriaceae family. This is especially prevalent in the pathotypes of Escherichia coli (E. coli). Moreover, in clinical laboratories, it is mistakenly identified as E. coli or even Hafnia alvei (H. alvei). This study was performed for the first time in Iran to identify $E$. albertii by PCR method from a sample of urinary and gastrointestinal infections obtained from clinical laboratories in Kermanshah, which were distinguished as E. coli.

\section{Methods}

In this study, 60 urinary samples and $40 \mathrm{fecal}$ samples that were identified as $E$. coli by phenotypic and biochemical methods in clinical laboratories. The samples were re-evaluated in the first step in terms of specific phenotypic and biochemical characteristics of $E$. coli. Subsequently, DNA was extracted from the isolates by the phenol method. Then, two lysP and mdh genes were detected for $E$. albertii and the uidA gene for $E$. coli by PCR using specific primers pairs.

\section{Results}

The results obtained from phenotypic and biochemical tests indicated that all samples were consistent with E. coli characteristics. However, findings from PCR showed that out of a total of 100 samples, specific genes of E. coli were identified in 6 samples (6\%) and uidA gene in 94 remaining samples (94\%). Of these 6 samples, 5 samples were urinary tract infections, and only one was a gastrointestinal infection.

\section{Conclusion}

The findings of this study show that $E$. albertii can be considered as one of the causes of urinary and gastrointestinal infections that are mistakenly identified in clinical laboratories as $E$. coli.Therefore, the use of molecular methods for accurate and definitive diagnosis of bacteria can be useful.

\section{Background}

Infectious diseases are always a threat to health and life, and they impose huge costs on families and the health-care system of the country every year. Infections related to gastrointestinal and urinary tract 
infections are of particular importance. A high proportion of these infections are attributed to the genus Escherichia from the Enterobacteriaceae family (1-4).

Escherichia albertii is a relatively new member of this bacterial family, and there is strong evidence that the bacterium plays a role in many global conflicts. Its misdiagnosis as Enteropathogenic Escherichia Coli (EPEC), Enterohemorrhagic Escherichia coli (EHEC), or other pathogenic bacteria has continued from the past to the present. Recently, its pathogenic potential has been strengthened by identifying strains with multiple antibiotic resistance (5-7).

Epidemiology, transmissibility, prevalence, pathogenicity, virulence factors, and antibiotic resistance in this emerging bacterium remain a challenge, and information about it is very poor. Its misdiagnosis as $E$. coli and the lack of a reliable diagnostic method to differentiate it are important points that have led to further investigation of $E$. albertii to identify its unique behaviors and characteristics. Comprehensive knowledge of the features of $E$. albertii, as a type of intestinal pathogen in humans and awareness of its prevalence, requires more analysis from different sources, different hosts, and the use of more accurate identification methods.

The uidA gene is one of the specific housekeeping genes in E. coli that encodes beta-di-glucuronidase and is considered one of the virulence markers in E. coli. Numerous studies have used this gene to identify $E$. coli, and PCR methods based on the diagnosis of this gene have been repeatedly used to diagnose E.coli (8-11). On the other hand, to identify E. albertii, tracking of two genes of $m d h$ (Encoding Malate dehydrogenase) and $l y s P$ (Encoding Lysine Permease) as specific and protected genes in $E$. albertii is performed in the form of a multiplex PCR method $(8-10,12,13)$. Also rpoB gene sequencebased identification, Multilocus sequence typing (MLST), or Whole Genome Sequencing (WGS) methods have been proposed, one of the limitations of which is being time-consuming to complete the results (10, 13-15).

As can be seen, the species of $E$. albertii is considered a human pathogen that may be ignored due to weakness in diagnosis. Moreover, the prevalence of this species in Iran is unknown. Therefore, the present study aimed to investigate the prevalence of $E$. albertii and its differentiation from E. coli in clinical samples of patients with diarrhea and urinary tract infections in Kermanshah using molecular methods.

\section{Methods}

This is a cross-sectional-analytical study. The study population was the cultures of urine and fecal clinical samples collected from laboratories in Kermanshah. 180 culture samples belonging to 180 clinical samples were collected during 6 months (From February 2018 to July 2018), which after initial tests, a total of 100 samples infected with $E$. coli were identified. Finally, these 100 samples were examined to track study objectives. Samples of urine and fecal culture included 60 and 40 cases, respectively.

\section{Culturing of samples}


In the research laboratory, subcultures were prepared from cultures suspected of containing $E$. coli obtained from fecal and urinary specimens (Positive lactose and negative lactose) and biochemical tests including TSI, SIM, MRVP, Simon citrate, Urease, lysine, phenylalanine, and culture on the MacConkey agar were performed to identify E. coli (16).

\section{Preparation of microbial stock}

To make the isolates usable in later stages, including molecular tests, the microbial stock was prepared from pure isolates that were detected $E$. coli using biochemical tests. A preservation medium (Including glycerol and liquid $\mathrm{BHI}$ medium) was used for this purpose. The pure bacterial isolates were then placed in tubes and after two hours of heating stored in a $20^{\circ} \mathrm{C}$ freezer (17).

\section{Genomic DNA extraction}

In the present study, DNA extraction was performed by the Phenol-Chloroform-Isoamyl method (16).

\section{Determination of quality and quantity of extracted genomic DNA}

To determine the quantity and quality of DNA, electrophoresis was used on $0.8 \%$ agarose gel, and the quality of the band was assessed using Ethidium bromide and placing the gel inside the Gel Document device.

\section{Polymerase chain reaction (PCR)}

Isolates that belonged to $E$. coli (Negative lactose and positive lactose) based on biochemical tests were nominated to track down $E$. albertii. For this purpose, three genes of uid $A, m d h$, and $l y s P$ were evaluated using the PCR method.

In the present study, the polymerase chain reaction was performed using a thermocycler device in a volume of $20 \mu \mathrm{l}$. The materials required for each reaction are shown in Table 1.

\section{Primer selection}

The primers of the three required genes ( $u i d A, m d h$, and $l y s P$ ) were purchased from CinnaGen Company (Iran). The selected primer pairs were diluted (1:10) according to the defined standard by adding specific amounts of sterile distilled water and a working solution was prepared from them (Table 2).

\section{Thermal cycling of PCR reaction}

The thermal cycle was first performed with an initial denaturation at $95^{\circ} \mathrm{C}$ for $5 \mathrm{~min}$, followed by 35 cycles. During these 35 cycles, denaturation at $95^{\circ} \mathrm{C}$ for $30 \mathrm{~s}$, the primer annealing at different temperatures for each primer (Annealing temperatures in this study for $u i d A, m d h$, and lysP primers were 67,65 , and $64^{\circ} \mathrm{C}$, respectively) was performed for $30 \mathrm{~s}$ and the extension step was performed at $72^{\circ} \mathrm{C}$ for $60 \mathrm{~s}$. Finally, after the cycles were completed, the final extension of the samples was performed at $72^{\circ} \mathrm{C}$ 
for 5 min (Table 3). After the cycles were completed, the samples were removed from the device and stored at $4^{\circ} \mathrm{C}$ until electrophoresis was performed (10 and 11 with minor modifications).

\section{Electrophoresis of PCR products on agarose gel}

DNA electrophoresis was performed horizontally in $2 \%$ agarose gel. The gel was placed inside the gel documentation device and the proliferated DNA bands were compared by the indicator DNA to view the desired bands.

\section{Results}

As mentioned earlier, during the initial processing, 100 samples (Negative lactose and positive lactose samples suspected of $E$. coli), including 60 urine samples and 40 fecal samples, were sent to the research laboratory for phenotypic and complementary biochemical diagnosis and molecular testing to identify $E$. albertii.

\section{Results from phenotypic and biochemical tests}

Biochemical tests performed on 100 samples, including TSI, SIM, MRVP, Simon citrate, urease, lysine, phenylalanine, and culture on MacConkey agar indicated that they belonged to $E$. coli.

\section{The PCR results of uidA, $m d h$, and $l y s P$ genes}

The results of the polymerase chain reaction of 100 samples showed that $94 \%$ of them were $E$. coli (Positive uidA gene) (Figs. 1) and $6 \%$ of them were positive in terms of tracking two specific genes of $E$. albertii ( $m d h$ and $l y s P$ ) (Fig. 2 and 3). On the other hand, these 6 isolates were negative for the uidA gene. Five isolates of these 6 cases were related to the urinary tract and one to gastrointestinal infections.

\section{Discussion}

The share of Escherichia, especially $E$. coli, is significant in urinary and gastrointestinal infections $(3,4$, and 18). In recent years, $E$. albertii has been reported to cause gastrointestinal infections in some cases of epidemics, and the results indicated that $E$. albertii resembles $E$. coli pathotypes $(19,20)$. This has challenged a range of studies to verify the diagnosis of $E$. coli pathotypes, especially EPEC, in recent years. Thus, it was proved that $E$. albertii was mistakenly identified as EPEC due to its unknown features and similar phenotypic and biochemical characteristics to $E$. coli $(12,21$, and 22). The reliable classification of diarrhea-causing bacteria into distinct pathotypes requires molecular tools, and the unavailability of this equipment in clinical laboratories has led to misdiagnosis and neglect of some pathogens, including E. albertii (22). Recently, researchers, have examined this unknown species in terms of prevalence, biochemical characteristics, pathogenicity, and virulence factors. Although studies in this area are increasing day by day, there is still insufficient information about these indicators in E. albertii. 
The study of this bacterial species is of particular importance since some findings have obscured the information from previous research. Therefore, given the importance of $E$. albertii as a lesser-known bacterial species and its importance in gastrointestinal and urinary tract infections and its neglect in diagnosis, for the first time in Iran (As far as the authors know) the present study identified $E$. albertii among urinary and fecal samples collected from clinical laboratories in Kermanshah province. These specimens were previously identified as E. coli.

Of the 100 clinical samples, 94 were positive for the uidA gene (Specific for $E$. coli) and using the specific genes of $E$. albertii (lysP and $m d h), 6$ cases (6\%) of $E$. albertii were finally identified. The uidA gene was not found in these six samples. Of the 6 cases of $E$. albertii, 5 cases belonged to urinary tract infections. It is believed that the origin of $E$. coli, which causes urinary tract infections, is intestinal flora (23). As a result, the gastrointestinal tract can be the origin of $E$. albertii identified from urinary samples in the present study.

To identify $E$. albertii, similar studies have traced two genes of $l y s P$, and $m d h$. Nimri reported that out of a total of 250 isolates obtained in about ten years from the feces of people with diarrhea, 48 cases of $E$. albertii were identified using the lysP and $m d h$ genes. The uidA gene was not found in these 48 isolates. It should be noted that these specimens had previously been identified as $E$. coli (8).

Aoshima also reported 6 E. albertii isolates from 20 phenotypically recognized $E$. coli samples by identifying the lys $P$ and $m d h$ genes in a population with a gastrointestinal infection of food origin (12).

By tracking the eae gene and sequencing it, Ooka identified 21 out of 31 samples related to the gastrointestinal infection as $E$. albertii. They were initially diagnosed as $E$. coli (27). In another study, Ooka reported that out of a total of 278 samples from the human, animal, and environmental sources previously identified as $E$. coli using common diagnostic methods, 26 were identified as $E$. albertii using MLST analysis of the eae gene. 14 cases of them belonged to human samples (21).

Hinenoya re-examined 20 strains of $E$. coli isolated from diarrheal infections. He identified all 20 isolates as $E$. albertii by MLST analysis of housekeeping genes of $E$. albertii (24).

Ori et al., in a 6-year care program re-examined diarrhea-causing $E$. coli isolates. They identified $10 E$. albertii cases out of a total of 693 isolates by tracking specific genes including cdgR, DNA-binding transcription activating gene in cysteine biosynthesis, and palmitoyl-acyl carrier protein-depended acetyltransferase gene (22).

In a research conducted by Lindsey, out of a total of 1,644 samples of chicken carcasses over one year at the slaughterhouse, lys $P$ and $m d h$ genes were positive in 61 isolates, which were identified as possible $E$. albertii species. However, the sequencing of the $r p o B$ gene reduced the number of $E$. albertii to 27 (14).

In general, due to the lack of a specific diagnostic protocol for $E$. albertii, different studies have used different methods and specific genes to identify it, and this information is constantly changing. It can be argued that although most studies have identified the two genes of $l y s P$ and $m d h$ as specific genes in the 
diagnosis of $E$. albertii, in several studies these two genes have not been able to identify all E. albertii. Therefore, efforts have been made to design more specific areas of the genome $(10,13-15)$.

Also, there is a discrepancy in the findings of the phenotypic and biochemical characteristics of E. albertii. For example, E. albertii was previously considered as a type of negative lactose, but a recent study found that strains of $E$. albertii could ferment the lactose (26). One of the reasons for the limited recognition of the phenotypic and biochemical properties of $E$. albertii is the small number of known strains to date (14).

In general, there is no sufficient information about the features of $E$. albertii to isolate and diagnose it optimally. As a result, it is difficult to identify the true prevalence of infections associated with $E$. albertii (24).

In several studies, the role of $E$. albertii as a potential and related pathogen in cases of gastroenteritis and diarrhea in humans has been confirmed (14 and 25-30). In countries such as Japan and Norway, the number of infections caused by $E$. albertii is increasing, which is a warning sign that the bacterium is causing problems around the world (24).

E. albertii is important not only for its pathogenicity and its role in gastroenteritis in the world but also for its resistance to certain antibiotics $(6,7)$. Therefore, it is important to continuously examine patients with diarrhea and urinary tract infections to detect $E$. albertii. Deaths among birds are another reason for global attention to $E$. albertii. The bacterium has also been isolated from animals such as pigs, cats, and in some cases from environmental and food contamination $(21,31-33,98-100)$. As a result, epidemiological studies should include not only the clinical level but also animal and environmental patterns such as water and food.

In the first step, the study of the frequency of $E$. albertii in the world can help further identify it. Epidemiological studies also help identify pathogenic strains, biochemical characteristics, and virulence genes. Finally, the integration of data and results leads to a comprehensive and accurate definition of the characteristics of $E$. albertii. In general, it can be said that in the future, diagnostic tests for $E$. albertii will be routinely performed in clinical laboratories to differentiate it from other members of the Enterobacteriaceae family.

\section{Conclusions}

As far as the authors know, the present study is the first report on the identification and separation of $E$. albertii from gastrointestinal and urinary tract infections in Iran. The results show that $E$. albertii is one of the possible causes of diarrhea, gastroenteritis, and urinary tract infections. Therefore, it is necessary to study and recognize this bacterial species as much as possible. Extensive and comprehensive epidemiological studies in Iran and other parts of the world are recommended using well-known molecular methods to achieve preventive and therapeutic goals before major conflicts caused by $E$. albertii. 


\section{Abbreviations}

PCR: Polymerase Chain Reaction.

\section{Declarations}

\section{Acknowledgements}

We thank Mr. Houman Shirvani for his assistance.

\section{Authors' contributions}

All authors contributed to the study conception and design. AF designed the study, performed the statistical analysis, conducted data analysis and wrote the manuscript. AN and BRZ participated in sample collection and carried out the bacteriological and molecular tests. All authors read and approved the final manuscript.

\section{Funding}

Not applicable.

\section{Availability of data and materials}

Data in this study is available upon request from corresponding author.

\section{Ethics approval and consent to participate}

Bacterial samples were collected from clinical laboratories which patients have previously been approved for use in medical research. Explanations were written to Editorial manager.

\section{Consent for publication}

Not applicable.

\section{Competing interests}

The authors declare that they have no competing interests.

\section{References}

1. Estrada-Garcia T, Lopez-Saucedo C, Thompson-Bonilla R, Abonce M, Lopez-Hernandez D, Santos JI, et al. Association of diarrheagenic Escherichia coli pathotypes with infection and diarrhea among Mexican children and association of atypical enteropathogenic $E$. coli with acute diarrhea. J CLIN MICROBIOL. 2009;47(1):93-8. 
2. Croxen MA, Finlay BB. Molecular mechanisms of Escherichia coli pathogenicity. Nat Rev Microbiol. 2010;8(1):26.

3. Makobe CK, Sang WK, Kikuvi G, Kariuki S. Molecular characterization of virulence factors in diarrhoeagenic Escherichia coli isolates from children in Nairobi, Kenya. J INFECT DEV COUNTR. 2012;6(08):598-604.

4. Harrington SM, Dudley EG, Nataro JP. Pathogenesis of enteroaggregative Escherichia coli infection. FEMS Microbiol Lett. 2006;254(1):12-8.

5. Albert MJ, Alam K, Islam M, Montanaro J, Rahaman A, Haider K, et al. Hafnia alvei, a probable cause of diarrhea in humans. INFECT IMMUN. 1991;59(4):1507-13.

6. Perez KL, Alam MJ, Castillo A, Taylor TM. Antibiotic resistance and growth of the emergent pathogen Escherichia albertii on raw ground beef stored under refrigeration, abuse, and physiological temperature. J Food Prot. 2013;76(1):124-8.

7. Li Q, Wang H, Xu Y, Bai X, Wang J, Zhang Z, et al. Multidrug-Resistant Escherichia albertii: Cooccurrence of $\beta$-Lactamase and MCR-1 Encoding Genes. FRONT MICROBIOL. 2018;9:258.

8. Nimri LF. Escherichia albertii, a newly emerging enteric pathogen with poorly defined properties. DIAGN MICR INFEC DIS. 2013;77(2):91-5.

9. Konno T, Yatsuyanagi J, Takahashi S, Kumagai Y, Wada E, Chiba M, et al. Isolation and identification of Escherichia albertii from a patient in an outbreak of gastroenteritis. JPN J INFECT DIS. 2012;65(3):203-7.

10. Hyma KE, Lacher DW, Nelson AM, Bumbaugh AC, Janda JM, Strockbine NA, et al. Evolutionary genetics of a new pathogenic Escherichia species: Escherichia albertii and related Shigella boydii strains. J Bacteriol. 2005;187(2):619-28.

11. Gómez-Duarte OG, Arzuza O, Urbina D, Bai J, Guerra J, Montes O, et al. Detection of Escherichia coli enteropathogens by multiplex polymerase chain reaction from children's diarrheal stools in two Caribbean-Colombian cities. FOODBORNE PATHOG DIS. 2010;7(2):199-206.

12. Asoshima N, Matsuda M, Shigemura K, Honda M, Yoshida H, Hiwaki H, et al. Identification of Escherichia albertii as a causative agent of a food-borne outbreak occurred in 2003. JPN J INFECT DIS. 2014;67(2):139-40.

13. Murakami K, Etoh Y, Tanaka E, Ichihara S, Horikawa K, Kawano K, et al. Shiga toxin 2f-producing Escherichia albertii from a symptomatic human. JPN J INFECT DIS. 2014;67(3):204-8.

14. Lindsey RL, Fedorka-Cray PJ, Abley M, Turpin JB, Meinersmann RJ. Evaluating the occurrence of Escherichia albertii in chicken carcass rinses by PCR, Vitek analysis, and sequencing of the rpoB gene. Appl Environ Microbiol. 2015;81(5):1727-34.

15. Lindsey RL, Garcia-Toledo L, Fasulo D, Gladney L, Strockbine N. Multiplex polymerase chain reaction for identification of Escherichia coli, Escherichia albertii and Escherichia fergusonii. J Microbiol Methods. 2017;140:1-4.

16. Foroughi A, Ramezan-Ghanbari SH. The Frequency of Stx1 and Stx2 Genes in Uropathogenic Escherichia coli Isolated From Patients in Kermanshah, Iran. JEP. 2019;1(2):41-6. 
17. Al-Kobaisi MF. Jawetz. Melnick \& Adelberg's Medical Microbiology: 24(th. Edition: Sultan Qaboos Univ Med J. 2007 Dec;7(3):273-5.

18. Brooks GF, Butel JS, Morse SA. Medical microbiology. United States, 25th. 2006.

19. Ooka T, Ogura Y, Katsura K, Seto K, Kobayashi H, Kawano K, et al. Defining the genome features of Escherichia albertii, an emerging enteropathogen closely related to Escherichia coli. GENOME BIOL EVOL. 2015;7(12):3170-9.

20. Baba A, Ebuchi S, Uryu K, Hiwaki H, Ogata K, Washimi E, et al. An outbreak of water-borne gastroenteritis caused by diarrheagenic Escherichia coli possessing eae gene. Jpn J Infect Dis. 2006;59(1):59-60.

21. Ooka T, Seto K, Kawano K, Kobayashi H, Etoh Y, Ichihara S, et al. Clinical significance of Escherichia albertii. Emerg Infect Dis. 2012;18(3):488.

22. Ori E, Takagi E, Andrade T, Miguel B, Cergole-Novella M, Guth B, et al. Diarrhoeagenic Escherichia coli and Escherichia albertii in Brazil: pathotypes and serotypes over a 6-year period of surveillance. EPIDEMIOL INFECT. 2018:1-9.

23. Zhang $L$, Foxman $B$, Marrs $C$. Both urinary and rectal Escherichia coli isolates are dominated by strains of phylogenetic group B2. J CLIN MICROBIOL. 2002;40(11):3951-5.

24. Hinenoya A, Yasuda N, Mukaizawa N, Sheikh S, Niwa Y, Awasthi SP, et al. Association of cytolethal distending toxin-II gene-positive Escherichia coli with Escherichia albertii, an emerging enteropathogen. INT J MED MICROBIOL. 2017;307(8):564-71.

25. Huys G, Cnockaert M, Janda JM, Swings J. Escherichia albertii sp. nov., a diarrhoeagenic species isolated from stool specimens of Bangladeshi children. INT J SYST EVOL MICR. 2003;53(3):807-10.

26. Maheux A, Boudreau D, Bergeron $M$, Rodriguez M. Characterization of $E$ scherichia fergusonii and $E$ scherichia albertii isolated from water. J Appl Microbiol. 2014;117(2):597-609.

27. Ooka T, Tokuoka E, Furukawa M, Nagamura T, Ogura Y, Arisawa K, et al. Human gastroenteritis outbreak associated with Escherichia albertii, Japan. Emerg Infect Dis. 2013;19(1):144.

28. Brandal LT, Tunsjø HS, Ranheim TE, Løbersli I, Lange H, Wester AL. Shiga toxin 2a in Escherichia albertii. J CLIN MICROBIOL. 2015;53(4):1454-5.

29. Hinenoya A, Yasuda N, Hibino T, Shima A, Nagita A, Tsukamoto T, et al. Isolation and characterization of an Escherichia albertii strain producing three different toxins from a child with diarrhea. JPN J INFECT DIS. 2017;70(3):252-7.

30. Stock I, Rahman M, Sherwood KJ, Wiedemann B. Natural antimicrobial susceptibility patterns and biochemical identification of Escherichia albertii and Hafnia alvei strains. DIAGN MICR INFEC DIS. 2005;51(3):151-63.

31. Wang H, Li Q, Bai X, Xu Y, Zhao A, Sun H, et al. Prevalence of eae-positive, lactose non-fermenting Escherichia albertii from retail raw meat in China. EPIDEMIOL INFECT. 2016;144(1):45-52.

32. Grillova L, SEDLÁČEK I, Pachnikova G, STAŇKOVÁ E, ŠVEC P, Holochova P, et al. Characterization of four Escherichia albertii isolates collected from animals living in Antarctica and Patagonia. J VET 
MED SCl. 2018;80(1):138 - 46.s Escherichia. Applied and environmental microbiology. 2009;75(20):6534-44.

33. Oaks JL, Besser TE, Walk ST, Gordon DM, Beckmen KB, Burek KA, et al. Escherichia albertii in wild and domestic birds. Emerg Infect Dis. 2010;16(4):638.

34. Hinenoya A, Shima K, Asakura M, Nishimura K, Tsukamoto T, Ooka T, et al. Molecular characterization of cytolethal distending toxin gene-positive Escherichia coli from healthy cattle and swine in Nara, Japan. BMC Microbiol. 2014;14(1):97.

35. Luo C, Walk ST, Gordon DM, Feldgarden M, Tiedje JM, Konstantinidis KT. Genome sequencing of environmental Escherichia coli expands understanding of the ecology and speciation of the model bacterial species. Proc Natl Acad Sci USA. 2011:201015622.

36. Rahman MZ, Akter S, Azmuda N, Sultana M, Weill F-X, Khan SI, et al. Serological cross-reaction between 0-antigens of Shigella dysenteriae type 4 and an environmental Escherichia albertii isolate. Curr Microbiol. 2013;67(5):590-5.

\section{Tables}

Table 1. Optimized Reaction Components

\begin{tabular}{|c|c|}
\hline (Volume ( $\mathrm{ul}$ & Sample components \\
\hline 12.6 & DD water \\
\hline 2 & Buffer (10X) PCR \\
\hline 1.5 & (MgCl2 (50 mM \\
\hline 0.4 & (dNTPs (10 mM \\
\hline (From each one) 1.2 & Primers \\
\hline 0.3 & (Taq DNA Polymerase (5 U/pl \\
\hline 2 & Template DNA (10 ng/pl) \\
\hline 20 & Sum \\
\hline
\end{tabular}

Table 2. Primer Sequences Used in This Study

\begin{tabular}{|c|c|c|c|}
\hline Gene & Sequence ('3-'5) & Product size (bp) & Reference \\
\hline uidA & $\begin{array}{l}\text { 5'-GCGTCTGTTGACTGGCAGGTGGTGG -3' } \\
\text { 5'-GTTGCCCGCTTCGAAACCAATGCCT -3' }\end{array}$ & 503 & \\
\hline$m d h$ & $\begin{array}{c}\text { 5'-CTG GAAGGC GCA GAT GTG GTA CTG ATT-3' } \\
\text { 5'-CTT GCT GAA CCA GAT TCT TCA CAA TAC } \\
\text { CG-3' }\end{array}$ & 115 & 10 \\
\hline lysp & $\begin{array}{c}\text { 5'-GGG CGC TGC TTT CAT ATA TTC TT-3' } \\
\text { 5'-TCC AGA TCC AAC CGG GAG TAT CAG GA-3' }\end{array}$ & 252 & 10 \\
\hline
\end{tabular}


Table 3. PCR Temperature cycles

\begin{tabular}{|c|c|c|c|c}
\hline Cycle (s) & Time duration & Temperature & Step \\
\hline 1 & $5 \mathrm{~m}$ & $95^{\circ} \mathrm{C}$ & Heating \\
\hline \multirow{3}{*}{35} & $30 \mathrm{~s}$ & $95^{\circ} \mathrm{C}$ & Denaturing \\
\cline { 3 - 4 } & $30 \mathrm{~s}$ & $67^{\circ} \mathrm{C}$ & uidA & Anneling \\
\cline { 3 - 3 } & & $65^{\circ} \mathrm{C}$ & mdh & \\
\cline { 3 - 3 } & & $64^{\circ} \mathrm{C}$ & lysp & \\
\cline { 3 - 4 } & & $\mathrm{C}^{\circ} 72$ & Extension \\
\hline 1 & $50 \mathrm{~s}$ & $\mathrm{C}^{\circ} 72$ & Final extension \\
\hline
\end{tabular}

\section{Figures}

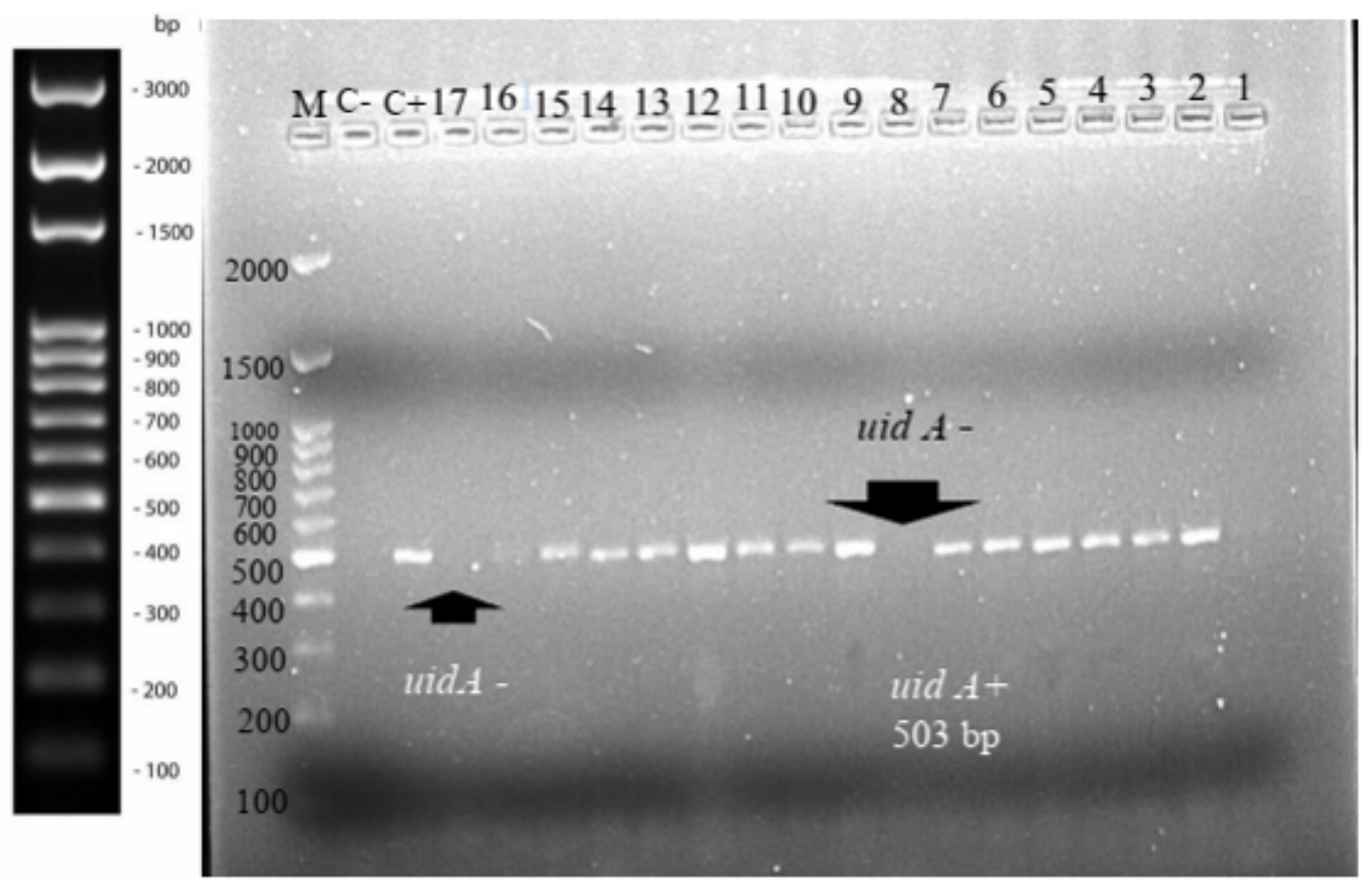

Figure 1

Electrophoresis of PCR products related to uidA gene (503 bp) on agarose gel $2 \%$, M: Laddre $100 \mathrm{bp}, \mathrm{C}+$ : Positive control, C-: Negative control. Samples 8 and 17 are negative for uidA. 


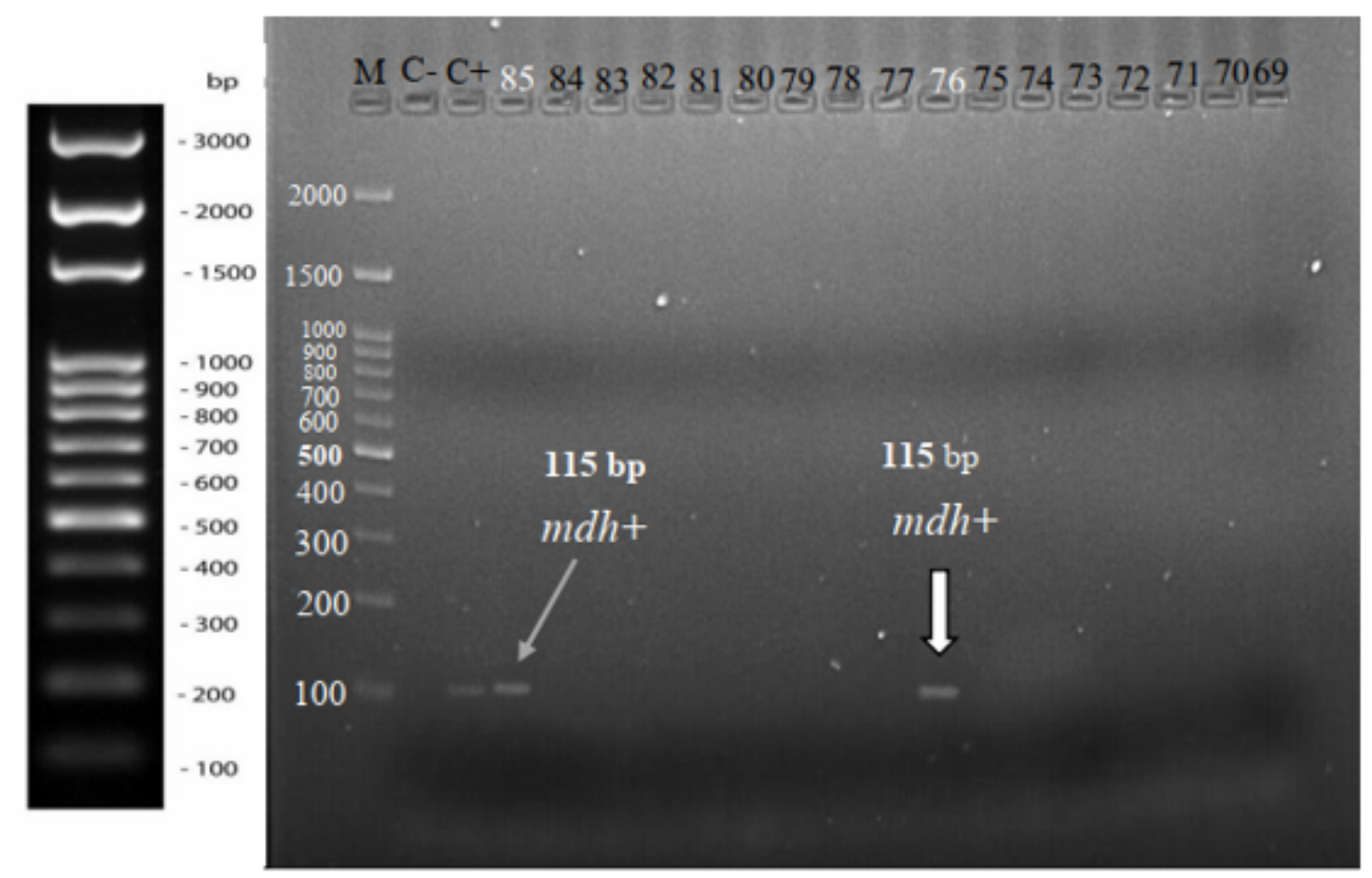

\section{Figure 2}

Electrophoresis of PCR products related to mdh gene (115 bp) on agarose gel 2\%, M: Laddre $100 \mathrm{bp}, \mathrm{C}+$ : Positive control, C-: Negative control. Samples 8 and 17 are positive for $\mathrm{mdh}$.

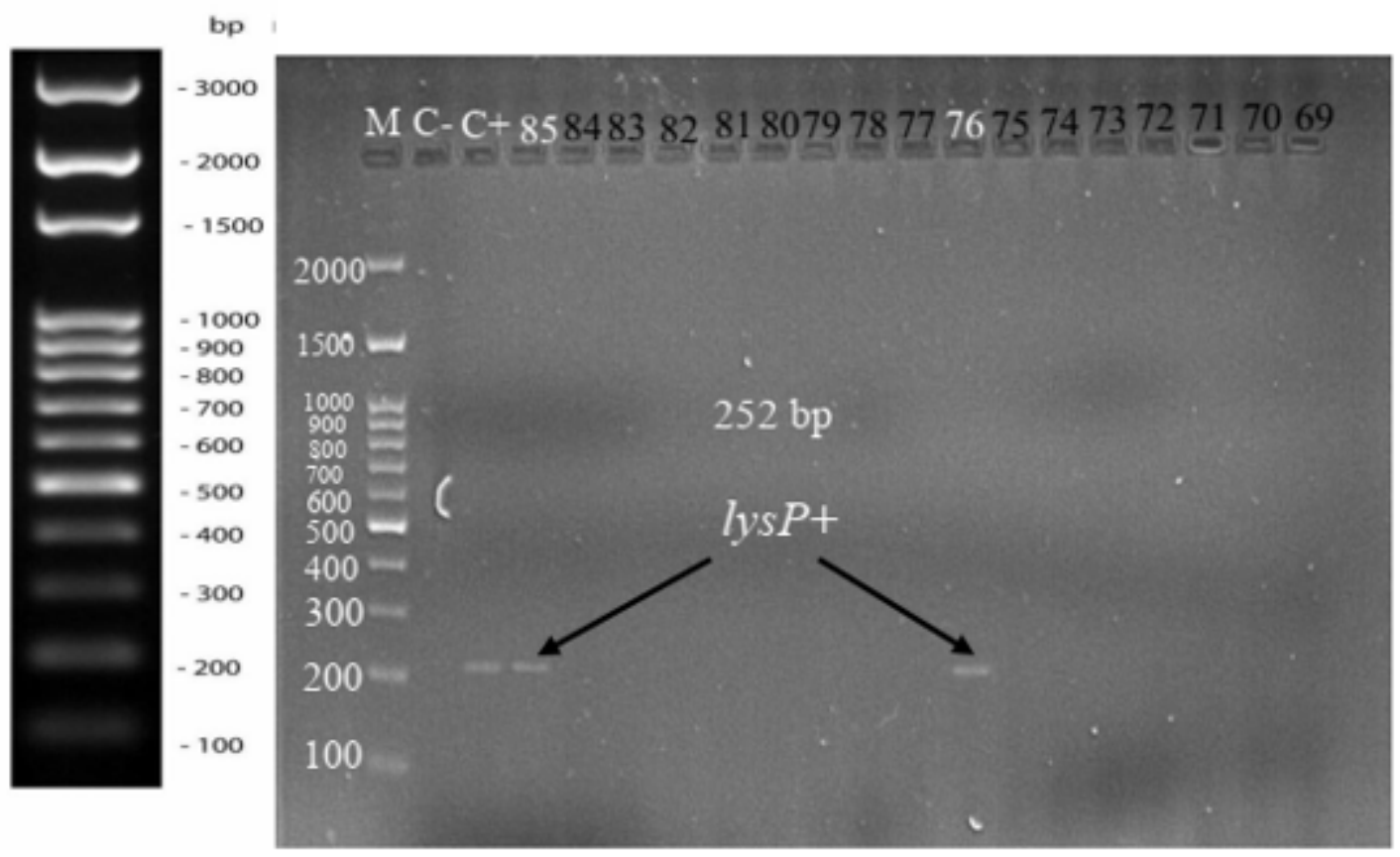

\section{Figure 3}


Electrophoresis of PCR products related to lysP gene (252 bp) on agarose gel $2 \%$, M: Laddre $100 \mathrm{bp}, \mathrm{C}+$ : Positive control, C-: Negative control. Samples 8 and 17 are positive for lysP.

\section{Supplementary Files}

This is a list of supplementary files associated with this preprint. Click to download.

- OriginalFigures.docx 